\title{
The influence of the usage of Idpe plastic waste as fine aggregate in light concrete bricks
}

\author{
Nursyamsi Nursyamsi ${ }^{1, *}$, Ivan Indrawan ${ }^{1}$, Prasetyo Ramadhan ${ }^{1}$ \\ ${ }^{1}$ Department Of Civil Engineering, University Of Sumatera Utara, Jalan Perpustakaan No.5, Medan, 20155, Indonesia
}

\begin{abstract}
It has been a long time that red bricks become the raw material for wall compilers. As the era develops, the bricks that are light, easy to compile and not time-consuming in manufacturing are invented. The composition materials for the building blocks are cement, sand and water. In this study, the use of sand in the bricks is reduced with LDPE plastic pellets. The reason for the use of LDPE plastic pellets as substitution of plastic materials is that LDPE plastic pellets have smaller density than sand does, so that it is expected that the brick becomes lighter although consists of the same composition and it can also reduce environmental problems as LDPE plastic waste is difficult to be decomposed by nature but gradually produced by humans that results in excessive waste The LDPE plastic pellets utilized are used LDPE plastics that are recycled into plastic pellets. The sample in this study consists of cylinder with diameter of $15 \mathrm{~cm}$ and height of $30 \mathrm{~cm}$ as sample of trial mixes test, concrete bricks with size of $40 \mathrm{~cm} \times 20 \mathrm{~cm} \mathrm{x} 10 \mathrm{~cm}$, cube with size of $5 \mathrm{~cm} \times 5 \mathrm{~cm} \times 5 \mathrm{~cm}$ and briquette. The trial mixes samples will be treated for 7 days and the brick, cube and briquette samples will be treated for 28 days prior to testing. Furthermore, the sample will be tested with visual, content weight, absorption, compressive strength and drag strength tests. The data analysis uses SNI 03-0349-1989 reference on Concrete Bricks as The Matching Composition for Walls. This study used a mixture of cement, sand and water with ratio of 1: 6: 0.24 , this composition was obtained from experiments on several specified compositions. The composition of substitute of plastic pellets used is $20 \%$ to the sand, the composition of this substitution is obtained from the experiments on several specified compositions. From the visual appearance, the content weight and absorption, both of normal brick and $20 \%$ LDPE pellets are included in the quality I, while the compressive strength test against the sample of normal brick results in quality I and 20\% LDPE pellets brick results in quality III.
\end{abstract}

\section{Introduction}

Concrete brick is a construction material made of a mixture of cement, sand and air which are then inserted into the mold according to standard and are pressed. It is used as an alternative to brick in constructing walls. Recently, the construction in Indonesia is growing rapidly, so that the need for building materials is increasing. As a result of the continuous increase in the construction industry, the need for building materials such as red bricks is also increased, therefore the need of alternative construction materials for making brick wall to substitute red brick, that is concrete brick.

Concrete brick is a non-structural wall building materials. The main raw material to manufacture concrete brick is cement and sand, however as sand has quite heavy load, so this time it is innovated to replace or substitute the sand into plastic pellets with some variation of mixing. The use of sand in the bricks is reduced with LDPE plastic pellets. The reason for the use of LDPE plastic pellets as substitution of plastic materials is that LDPE plastic pellets have smaller density than sand does, so that it is expected that the brick becomes lighter although consists of the same composition.

LDPE plastic is a material that we often encounter which is usually found on food wrappers or tools that are usually disposed after usage. Because of the high increase of plastic waste in the world, the use of shredded plastics has known a growing interest as recycled materials in civil engineering construction. The incorporation of waste in concrete provides additional advantages in terms of environmental and potential economic considerations [3]. 
Plastic has become a dangerous waste and difficult to reprocess. It takes a long time for the plastic to break down completely. At the time of the decomposition process, plastic waste will contaminate the soil, air, and water. If plastics are dumped in the soil, plastics will damage soil fertility and block the rate of water in the soil, whereas if plastic waste is burned, toxic fumes resulting from burning will be harmful to living things. When plastics are discharged into the waters, chemicals present in plastics will damage the marine ecosystem.

Plastics that have light physical properties can be used as one of the aggregate methods in reducing the weight unit of concrete or brick concrete [4]. Although these alternatives are feasible except for land-filling, recycling of plastic waste to produce new materials, such as cement composites, appears as one of the best solution for disposing of plastic waste, due to its economic and ecological advantages[5].

The development of concrete with nonconventional aggregate, such as polystyrene foam wastes, HDPE, polyethylene terephthalate (PET), and other plastic materials has been investigated for use in concrete in order to improve the properties of the concrete and reduce cost. The use of such plastic wastes in concrete will contribute to the sustainability of the concrete design and the natural environment [6].

Different types of plastic have been investigated these last years: polyethylene terephthalate (PET), highdensity polyethylene (HDPE) and polypropylene (PP). These studies have focussed on the effect of plastic addition in the workability of the fresh composites and in the mechanical strength of the hardened mixtures[710]. Ismail and AL-Hashmi (2008) have found that, as the percentage of waste plastic (consists of $80 \%$ polyethylene and $20 \%$ polystyrene) increases, the workability increases and the bulk density decreases[11]. This last result is due to the low density of plastic aggregates comparing to conventional ones. Naik et al. (1996) have found that post-consumer waste HDPE plastic can be successfully used in concrete as soft filler. They have shown that chemical treatment has a significant effect on performance of the plastic filler in concrete [12]. Nursyamsi and Winner (2017) have found that by using PET plastic waste as substitution of coarse aggregate in concrete as an alternative to reduce self weight can be used for light structural [13].

In this study, the use of sand in the bricks is reduced with LDPE plastic pellets. The sample in this study consists of cylinder with diameter of $15 \mathrm{~cm}$ and height of $30 \mathrm{~cm}$ as sample of trial mixes test, concrete bricks with size of $40 \mathrm{~cm} \times 20 \mathrm{~cm} \times 10 \mathrm{~cm}$, cube with size of 5 $\mathrm{cm} \times 5 \mathrm{~cm} \times 5 \mathrm{~cm}$ and briquette. The cylinder spesimens are used for compression strength for the trial mixes samples will be treated for 7 days and the brick, cube and briquette samples will be treated for 28 days prior to testing [14-15].

About the classification of the quality of concrete bricks based on SNI-3-0349-1989 for the use of the percentage of substitute of LDPE plastic waste with various percentage as the material to reduce the weight of the concrete bricks. From this standard, the author will also make a visual outcome test, content weight test, compressive strength test and tensile strength tests of that concrete brick that uses substituted materials of LDPE plastic waste.

\section{Research Method}

This research uses experimental research method. The factor of this research is the use of LDPE recycled plastic pellets composition as added ingredient in concrete brick by reducing the amount of sand, in this research the percentage of LDPE plastic pellets of $0 \%$, $20 \%, 25 \%, 30 \%$ and $50 \%$ of the weight of sand is used. The production of the test object of concrete bricks uses the research design of mixing comparison 1pc: $6 \mathrm{ps}$ that is obtained from the experimental comparison of $1 \mathrm{pc}$ : 6ps, 1pc: 7ps and 1pc: $8 \mathrm{ps}$ and for water content is also determined by experimental way with the first set of comparison of water used is $0.2 \%, 0.24 \%$ and $0.28 \%$.[1,2] The overall stages of this study are summarized as follows

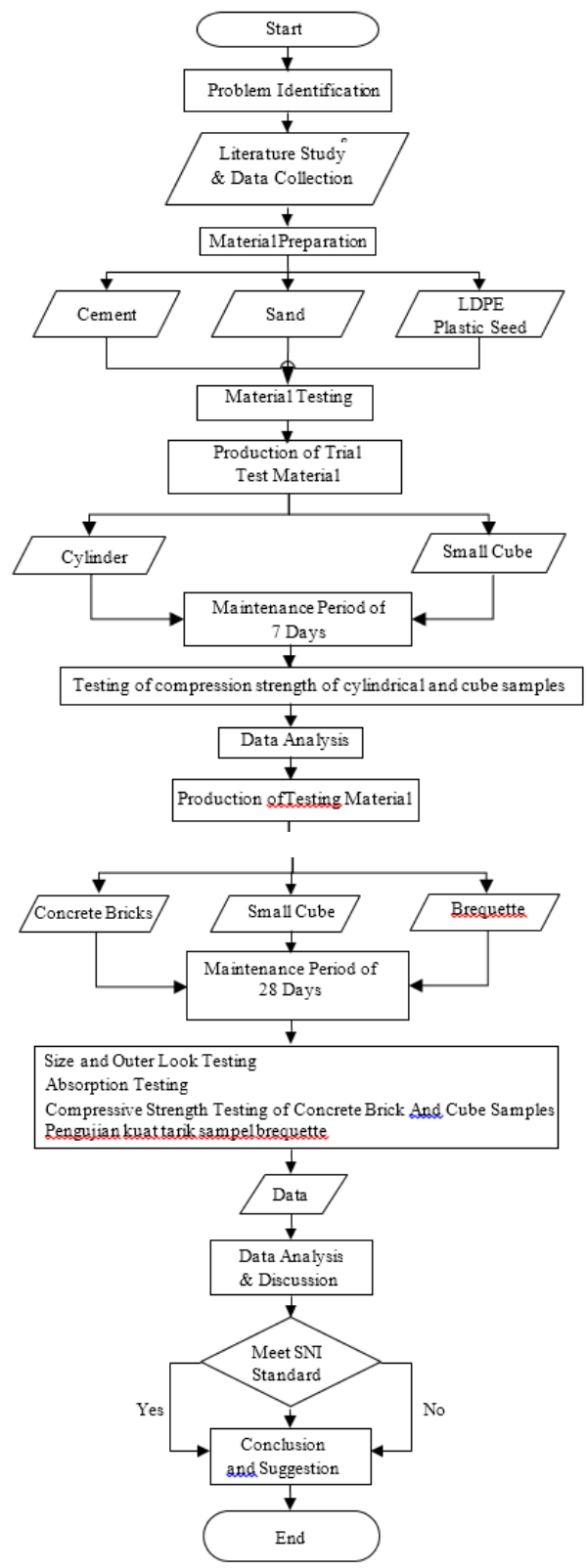

Fig. 1. Stages of Research Flowchart 


\section{Result}

\subsection{Trial Mixes}

Prior to making a comparative test object from the addition of pellets, we must first determine the ratio of the casting mixture. To determine the ratio of cement sand and water we use trial mixes. The test results are as follows:

\subsection{Test Result}

Table 1. Comparison of Visual Checking Result with Quality Requirement

\begin{tabular}{|c|c|c|c|}
\hline \multirow[b]{2}{*}{ Description } & \multicolumn{2}{|c|}{ Average Sample Condition } & \multirow[b]{2}{*}{$\begin{array}{c}\text { According to } \\
\text { SNI 03- } \\
\text { 0349-1989 }\end{array}$} \\
\hline & $\begin{array}{c}\text { Normal } \\
\text { Concrete } \\
\text { Bricks }\end{array}$ & $\begin{array}{c}\text { Concrete } \\
\text { Bricks + } \\
\text { LDPE } \\
\text { Plastic }\end{array}$ & \\
\hline \multicolumn{4}{|l|}{ 1.Fields } \\
\hline a. flatness & Flat & Flat & Flat \\
\hline b. fracture & Not cracked & Not cracked & Not cracked \\
\hline c. smooth & Smooth & Smooth & Smooth \\
\hline \multicolumn{4}{|l|}{ 2.Ribs } \\
\hline a. Elbow & Elbow & Elbow & Elbow \\
\hline b.Sharpness & Sharp & Sharp & Sharp \\
\hline c. Strength & Strong & Strong & Strong \\
\hline
\end{tabular}

Table 2. Comparison of Deviation of Average Device Size of Batako Tests against Quality Requirements

\begin{tabular}{|c|c|c|c|c|c|c|c|}
\hline \multirow[b]{2}{*}{ No. } & \multirow[b]{2}{*}{ Sample } & \multicolumn{2}{|c|}{$\begin{array}{c}\text { Average Length } \\
\text { (mm) }\end{array}$} & \multicolumn{2}{|c|}{$\begin{array}{c}\text { Average Width } \\
\text { (mm) }\end{array}$} & \multicolumn{2}{|c|}{$\begin{array}{c}\text { Average Height } \\
\text { (mm) }\end{array}$} \\
\hline & & $\begin{array}{c}\text { Test } \\
\text { Object }\end{array}$ & $\begin{array}{c}\text { SNI } \\
03- \\
0349- \\
1989\end{array}$ & $\begin{array}{c}\text { Test } \\
\text { Object }\end{array}$ & $\begin{array}{c}\text { SNI } \\
03- \\
0349- \\
1989\end{array}$ & $\begin{array}{c}\text { Test } \\
\text { Object }\end{array}$ & $\begin{array}{c}\text { SNI 03- } \\
0349- \\
1989\end{array}$ \\
\hline 1 & Normal & $\begin{array}{c}5 \mathrm{~mm} \\
\text { Tolerance } \\
\text { Limit }\end{array}$ & +1.4 & $\begin{array}{c}5 \mathrm{~mm} \\
\text { Tolerance } \\
\text { Limit }\end{array}$ & +0.2 & 100.6 & $\begin{array}{c}5 \mathrm{~mm} \\
\text { Tolerance } \\
\text { Limit }\end{array}$ \\
\hline 2 & $\begin{array}{c}20 \% \\
\text { LDPE } \\
\text { Plastic } \\
\text { Pellets }\end{array}$ & $\begin{array}{c}5 \mathrm{~mm} \\
\text { Tolerance } \\
\text { Limit }\end{array}$ & +1.6 & $\begin{array}{c}5 \mathrm{~mm} \\
\text { Tolerance } \\
\text { Limit }\end{array}$ & +1.2 & 101 & $\begin{array}{c}5 \mathrm{~mm} \\
\text { Tolerance } \\
\text { Limit }\end{array}$ \\
\hline
\end{tabular}

Table 3. Content Weight of Normal Brick Test Object

\begin{tabular}{|c|c|c|c|}
\hline No. & $\begin{array}{c}\text { Volume } \\
\left(\mathrm{cm}^{3}\right)\end{array}$ & $\begin{array}{l}\text { Weight } \\
\text { (g) }\end{array}$ & $\begin{array}{l}\text { Content } \\
\text { Weight } \\
\left(\mathrm{g} / \mathrm{cm}^{3}\right)\end{array}$ \\
\hline 1 & 8000 & 14102 & 1.762 \\
\hline 2 & 8000 & 14004 & 1.751 \\
\hline 3 & 8000 & 13956 & 1.745 \\
\hline 4 & 8000 & 15063 & 1.883 \\
\hline 5 & 8000 & 14460 & 1.808 \\
\hline \multicolumn{2}{|c|}{ Average } & 14317 & 1.789 \\
\hline
\end{tabular}

Table 4. Content Weight of 20\% LDPE Plastic Pellets Concrete Bricks Test Object

\begin{tabular}{|c|c|c|c|}
\hline No. & $\begin{array}{c}\text { Volume } \\
\left(\mathrm{cm}^{3}\right)\end{array}$ & $\begin{array}{l}\text { Weight } \\
\text { (g) }\end{array}$ & $\begin{array}{l}\text { Content } \\
\text { Weight } \\
\left(\mathrm{g} / \mathrm{cm}^{3}\right)\end{array}$ \\
\hline 1 & 8000 & 13123 & 1.640 \\
\hline 2 & 8000 & 12749 & 1.594 \\
\hline 3 & 8000 & 12640 & 1.580 \\
\hline 4 & 8000 & 12836 & 1.605 \\
\hline 5 & 8000 & 12879 & 1.610 \\
\hline \multicolumn{2}{|c|}{ Average } & 12845.4 & 1.606 \\
\hline
\end{tabular}


Table 5. Content Weight of Normal Cube Test Object

\begin{tabular}{|c|c|c|c|}
\hline No. & $\begin{array}{c}\text { Volume } \\
\left(\mathrm{cm}^{3}\right)\end{array}$ & $\begin{array}{l}\text { Weight } \\
\text { (g) }\end{array}$ & $\begin{array}{l}\text { Content } \\
\text { Weight } \\
\left(\mathrm{g} / \mathrm{cm}^{3}\right)\end{array}$ \\
\hline 1 & 125 & 250 & 2.000 \\
\hline 2 & 125 & 245 & 1.96 \\
\hline 3 & 125 & 244 & 1.952 \\
\hline 4 & 125 & 246 & 1.968 \\
\hline 5 & 125 & 245 & 1.960 \\
\hline 6 & 125 & 250 & 2.000 \\
\hline 7 & 125 & 236 & 1.889 \\
\hline 8 & 125 & 241 & 1.928 \\
\hline 9 & 125 & 239 & 1.912 \\
\hline 10 & 125 & 242 & 1.936 \\
\hline 11 & 125 & 237 & 1.896 \\
\hline 12 & 125 & 240 & 1.920 \\
\hline \multicolumn{2}{|c|}{ Average } & 242.92 & 1.943 \\
\hline
\end{tabular}

Table 6. Content Weight of 20\% LDPE Plastic Pellets Cube Test Object

\begin{tabular}{|c|c|c|c|}
\hline No. & $\begin{array}{c}\text { Volume } \\
\left(\mathrm{cm}^{3}\right)\end{array}$ & $\begin{array}{l}\text { Weight } \\
\text { (g) }\end{array}$ & $\begin{array}{l}\text { Content } \\
\text { Weight } \\
\left(\mathrm{g} / \mathrm{cm}^{3}\right)\end{array}$ \\
\hline 1 & 125 & 207 & 1.656 \\
\hline 2 & 125 & 215 & 1.720 \\
\hline 3 & 125 & 195 & 1.560 \\
\hline 4 & 125 & 212 & 1.696 \\
\hline 5 & 125 & 202 & 1.616 \\
\hline 6 & 125 & 203 & 1.624 \\
\hline 7 & 125 & 204 & 1.632 \\
\hline 8 & 125 & 180 & 1.440 \\
\hline 9 & 125 & 202 & 1.616 \\
\hline 10 & 125 & 203 & 1.624 \\
\hline 11 & 125 & 210 & 1.680 \\
\hline 12 & 125 & 212 & 1.696 \\
\hline \multicolumn{2}{|c|}{ Average } & 203.75 & 1.630 \\
\hline
\end{tabular}

\begin{tabular}{|c|c|c|c|c|c|}
\hline \multirow[b]{2}{*}{ No. } & \multirow[b]{2}{*}{$\begin{array}{c}\text { Dial } \\
\text { Reading } \\
(\mathbf{k N})\end{array}$} & \multirow[b]{2}{*}{$\begin{array}{l}\text { Compressive } \\
\text { Area Width } \\
\quad\left(\mathrm{cm}^{2}\right)\end{array}$} & \multicolumn{2}{|c|}{$\begin{array}{c}\text { Compressive } \\
\text { Strength }\left(\mathrm{Kg} / \mathrm{cm}^{2}\right) \\
\end{array}$} & \multirow[b]{2}{*}{ Quality } \\
\hline & & & $\begin{array}{c}\text { Measured } \\
\text { Compressive } \\
\text { Strength }\end{array}$ & $\begin{array}{c}\text { SNI } \\
\text { 03- } \\
\text { 0349- } \\
\text { 1989* }\end{array}$ & \\
\hline 1 & 280 & 280 & 101.97 & 90 & 1 \\
\hline 2 & 270 & 280 & 98.33 & 90 & 1 \\
\hline 3 & 275 & 280 & 100.15 & 90 & 1 \\
\hline 4 & 278 & 280 & 101.24 & 90 & 1 \\
\hline 5 & 272 & 280 & 99.06 & 90 & 1 \\
\hline \multicolumn{3}{|c|}{ Average } & 100.15 & 100 & 1 \\
\hline
\end{tabular}

*According to SNI, the compressive strength of the concrete brick of quality I, has a compressive strength requirement of each specimen is $90 \mathrm{Kg} / \mathrm{cm}^{2}$ with average Compressive Strength is $100 \mathrm{Kg} / \mathrm{cm}^{2}$

Table 7 The Result of Normal Concrete Brick

Absorption Test

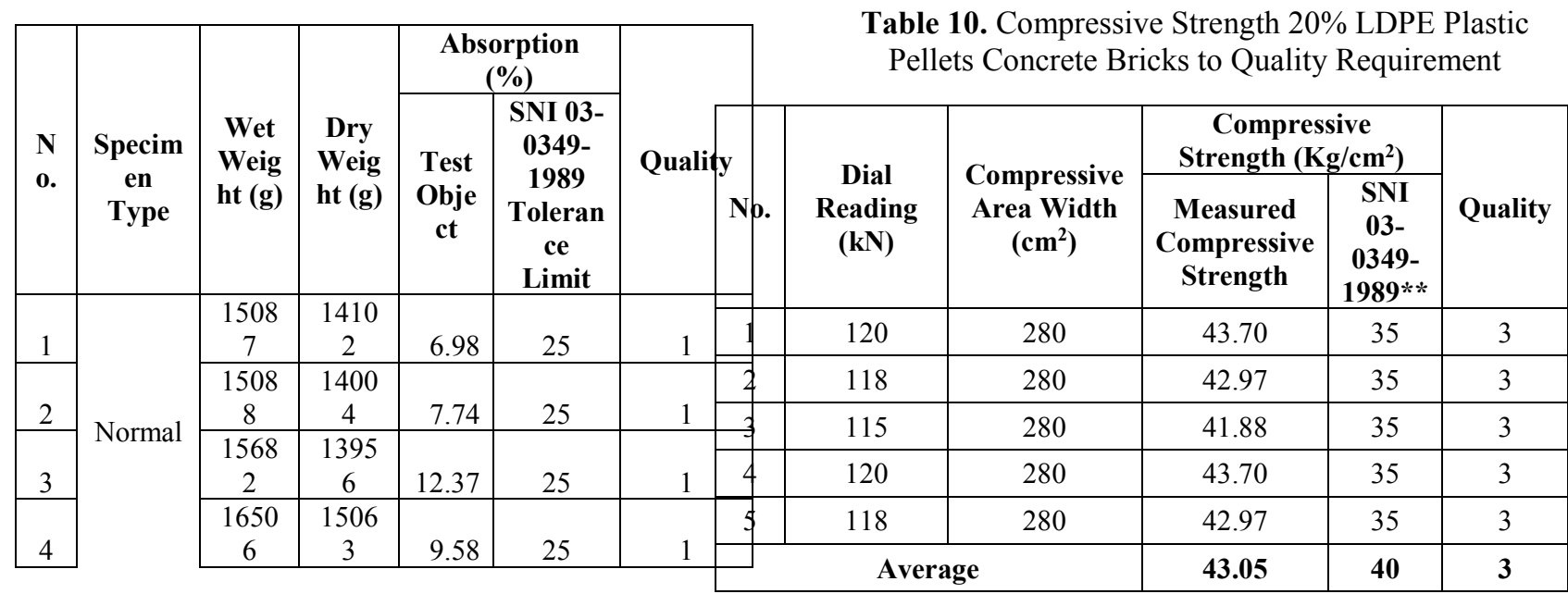


**According to SNI, the compressive strength of the concrete brick of quality III, has a compressive strength requirement of each specimen is $35 \mathrm{Kg} / \mathrm{cm}^{2}$ with average Compressive Strength is $40 \mathrm{Kg} / \mathrm{cm}^{2}$

Table 11. Compressive Strength of Normal Cubes Test

\begin{tabular}{|c|c|c|c|c|c|}
\hline & & & \multicolumn{2}{|c|}{$\begin{array}{c}\text { Compressive } \\
\text { Strength }\left(\mathbf{K g} / \mathbf{c m}^{2}\right)\end{array}$} & \multirow{2}{*}{ No. } \\
\cline { 4 - 5 } & $\begin{array}{c}\text { Dial } \\
\text { Reading } \\
(\mathbf{k N})\end{array}$ & $\begin{array}{c}\text { Compressive } \\
\text { Area Width } \\
\left(\mathbf{c m}^{2}\right)\end{array}$ & $\begin{array}{c}\text { Measured } \\
\text { Compressive } \\
\text { Strength }\end{array}$ & $\begin{array}{c}\text { SNI } \\
\mathbf{0 3 -} \\
\mathbf{0 3 4 9}\end{array}$ & Quality \\
$\mathbf{1 9 8 9 * *}$ & \\
\hline 1 & 15 & 25 & 61.18 & 35 & 3 \\
\hline 2 & 15 & 25 & 61.18 & 35 & 3 \\
\hline 3 & 10 & 25 & 40.79 & 35 & 3 \\
\hline 4 & 15 & 25 & 61.18 & 35 & 3 \\
\hline 5 & 12 & 25 & 48.95 & 35 & 3 \\
\hline 6 & 12 & 25 & 48.95 & 35 & 3 \\
\hline 7 & 12 & 25 & 48.95 & 35 & 3 \\
\hline 8 & 10 & 25 & 40.79 & 35 & 3 \\
\hline 9 & 12 & 25 & 48.95 & 35 & 3 \\
\hline 10 & 12 & 25 & 48.95 & 35 & 3 \\
\hline 11 & 15 & 25 & 61.18 & 35 & 3 \\
\hline 12 & 15 & 25 & 61.18 & 35 & 3 \\
\hline & Average & & $\mathbf{5 2 . 6 8}$ & $\mathbf{4 0}$ & $\mathbf{3}$ \\
\hline
\end{tabular}

Object to Quality Requirement

Table 12. Compressive Strength of 20\% LDPE Plastic Pellets Cube Test Object to Quality Requirement

\begin{tabular}{|c|c|c|c|c|c|}
\hline \multirow[b]{2}{*}{ No. } & \multirow[b]{2}{*}{$\begin{array}{c}\text { Dial } \\
\text { Reading } \\
(\mathbf{k N})\end{array}$} & \multirow[b]{2}{*}{$\begin{array}{l}\text { Compressive } \\
\text { Area Width } \\
\quad\left(\mathrm{cm}^{2}\right)\end{array}$} & \multicolumn{2}{|c|}{$\begin{array}{c}\text { Compressive Strength } \\
\left(\mathrm{Kg} / \mathrm{cm}^{2}\right)\end{array}$} & \multirow[b]{2}{*}{ Quality } \\
\hline & & & $\begin{array}{c}\text { Measured } \\
\text { Compressive } \\
\text { Strength }\end{array}$ & $\begin{array}{c}\text { SNI 03- } \\
\text { 0349- } \\
\text { 1989* }\end{array}$ & \\
\hline 1 & 28 & 25 & 114.21 & 90 & 1 \\
\hline 2 & 26 & 25 & 106.05 & 90 & 1 \\
\hline 3 & 26 & 25 & 106.05 & 90 & 1 \\
\hline 4 & 26 & 25 & 106.05 & 90 & 1 \\
\hline 5 & 24 & 25 & 97.89 & 90 & 1 \\
\hline 6 & 28 & 25 & 114.20 & 90 & 1 \\
\hline 7 & 22 & 25 & 89.73 & 90 & 1 \\
\hline 8 & 24 & 25 & 97.89 & 90 & 1 \\
\hline 9 & 24 & 25 & 97.89 & 90 & 1 \\
\hline 10 & 26 & 25 & 106.05 & 90 & 1 \\
\hline 11 & 22 & 25 & 89.73 & 90 & 1 \\
\hline 12 & 24 & 25 & 97.89 & 90 & 1 \\
\hline \multicolumn{3}{|c|}{ Average } & 101.97 & 100 & 1 \\
\hline
\end{tabular}

Table 13. Comparison of Tensile Strength of Normal Briquette Sample

\begin{tabular}{|c|c|c|c|c|}
\hline \multirow{2}{*}{ No. } & \multicolumn{2}{|c|}{$\begin{array}{c}\text { Measured } \\
\text { Tensile } \\
\text { Strength }\end{array}$} & \multirow{2}{*}{$\begin{array}{c}\text { Cross } \\
\text { Section } \\
\text { Area(cm }\end{array}$} & $\begin{array}{c}\text { Tension } \\
\text { (MPa) }\end{array}$ \\
\cline { 2 - 3 } & $\mathbf{k N}$ & $\mathbf{K g}$ & \\
\hline 1 & 1.2 & 122.36 & 8.61 & 1.39 \\
\hline 2 & 1.05 & 107.07 & 8.02 & 1.31 \\
\hline 3 & 1.1 & 112.17 & 7.39 & 1.49 \\
\hline 4 & 1.35 & 137.66 & 7.05 & 1.92 \\
\hline 5 & 1.5 & 152.96 & 8.52 & 1.76 \\
\hline 6 & 1.5 & 152.96 & 7.07 & 2.12 \\
\hline 7 & 1.25 & 127.46 & 7.02 & 1.78 \\
\hline 8 & 1.5 & 152.96 & 7.23 & 2.07 \\
\hline 9 & 1.6 & 163.15 & 7.91 & 2.02 \\
\hline 10 & 1.45 & 147.86 & 6.89 & 2.10 \\
\hline 11 & 2 & 203.94 & 11.74 & 1.70 \\
\hline 12 & 1.575 & 160.60 & 8.91 & 1.77 \\
\hline Average & $\mathbf{1 . 4 2}$ & $\mathbf{7 9 . 2 4}$ & & 1.79 \\
\hline
\end{tabular}

Table 14. Comparison of Tensile Strength of $20 \%$ LDPE Plastic Pellets Briquette Samples

\begin{tabular}{|c|c|c|c|c|}
\hline \multirow{2}{*}{ No. } & \multicolumn{2}{|c|}{$\begin{array}{c}\text { Measured } \\
\text { Tensile } \\
\text { Strength }\end{array}$} & $\begin{array}{c}\text { Cross } \\
\text { Section } \\
\text { Area(cm }\end{array}$ & \multirow{2}{*}{$\begin{array}{c}\text { Tension } \\
\text { (MPa) }\end{array}$} \\
\cline { 2 - 5 } & kN & Kg & \\
\hline 1 & 0.65 & 66.28 & 7.84 & 0.83 \\
\hline 2 & 0.7 & 71.38 & 7.29 & 0.96 \\
\hline 3 & 0.85 & 86.67 & 8.96 & 0.95 \\
\hline 4 & 0.75 & 76.48 & 8.4 & 0.89 \\
\hline 5 & 0.9 & 91.77 & 10.53 & 0.86 \\
\hline 6 & 0.6 & 61.18 & 8.37 & 0.72 \\
\hline 7 & 0.65 & 66.28 & 7.7 & 0.84 \\
\hline 8 & 1.025 & 104.52 & 7.56 & 1.36 \\
\hline 9 & 0.75 & 76.48 & 7.28 & 1.03 \\
\hline 10 & 0.8 & 81.58 & 7.83 & 1.02 \\
\hline 11 & 0.95 & 96.87 & 7.16 & 1.33 \\
\hline 12 & 0.7 & 71.38 & 7.15 & 0.98 \\
\hline Average & $\mathbf{0 . 7 8}$ & $\mathbf{7 9 . 2 4}$ & & 0.98 \\
\hline
\end{tabular}


From the results that have been obtained, substitution of LDPE plastic pellets to the sand can reduce the content weight of the brick as well as the compressive strength of the test material when the addition of LDPE plastic pellets decreased that is worth $57.02 \%$, the compressive strength test on the brick and cube test object has different values although still in the same quality because due to the effect of shape. In the test of tensile strength of the specimen with the addition of $20 \%$ of LDPE plastic pellets it decreased by $45.15 \%$, the absorption test also decreased by $23.09 \%$, which means that if it was added with the plastic pellets, the concrete brick has fewer cavities than the normal brick. The absorption test does not reflect porosity, but the interconnectivity of voids.

\section{Conclusions}

From the research results the conclusions obtained are as follows:

1. The average weight for normal brick is $1.789 \mathrm{~g} / \mathrm{cm}^{3}$.

2. The weight of the average contents for the brick using $20 \%$ LDPE plastic is obtained at $1.606 \mathrm{~g} / \mathrm{cm}^{3}$.

3. The average content weight for normal cube is 1943 $\mathrm{g} / \mathrm{cm}^{3}$.

4. The average content weight for cubes using $20 \%$ LDPE plastic pellets is $1,630 \mathrm{~g} / \mathrm{cm}^{3}$.

5. The average absorbance of normal bricks test specimens obtained is $9.246 \%$ and the brick test object using LDPE 20\% plastic substitution material was $7.111 \%$, both of which were less than $25 \%$ and included the classification of quality I.

6. The average compressive strength of normal brick object test obtained is $100.15 \mathrm{~kg} / \mathrm{cm}^{2}$ including the classification of quality I and concrete brick test specimen using substitute materials of LDPE plastic substitution material of $20 \%$ as much as $43.05 \mathrm{~kg} / \mathrm{cm}^{2}$ included in the classification of quality III.

7. The strength of the average cubical specimen object is $101.97 \mathrm{~kg} / \mathrm{cm}^{2}$ including the classification of quality I and the cube test object using 20\% LDPE plastic substitution material of $52.68 \mathrm{~kg} / \mathrm{cm}^{2}$ including the classification of quality III.

8. The average tensile strength of a normal briquette test object obtained was $18.22 \mathrm{~kg} / \mathrm{cm}^{2}$ while on LDPE $20 \%$ substitute plastic pellets test object $9.99 \mathrm{~kg} / \mathrm{cm}^{2}$ was obtained.

9. The content weight on LDPE $20 \%$ plastic pellets substitution can reduce up to $11.515 \%$ and in the cube it can reduce up to $16.123 \%$.

\section{Suggestions}

Based on the conclusions and previous discussion it can be suggested that:

1. The entire process of designing, preparation of materials and tools as well as the process of concrete brick construction until the maintenance process need to be taken care of very carefully, so as to produce concrete bricks with good quality.
2. There are numerous limitations in this study, therefore it is expected that for further research the following things could be conducted:

a. Brick molding needs to use compressor tool, as in this research the molding used is manually by using pounder.

b. Need to compare the use of LDPE plastic in other forms.

c. Need to investigate the amount of water needed as a material of cement reactor, for the optimum amount of water to be used to be obtained, as in this study the amount of water used was only based on trial mixes.

\section{References}

1. Hannawi K, Kamali-Bernard S, Prince W. Physical and mechanical properties of mortars containing PET and PC waste aggregates. Waste Manage. 30:2312-20. (2010)

2. Akcaozoglu S, Atis CD, Akcaozoglu K. An investigation on the use of shredded waste PET bottles as aggregate in lightweight concrete. Waste Manage (Oxford) 32:285-90. (2010)

3. Saikia N, De Brito J. Use of plastic waste as aggregate in cement mortar and concrete preparation: a review. Constr Build Mater. 34:385401. (2012)

4. Al Bakri, A. M. Mustafa, S. Mohammad Tamizi, dan A. R. Rafiza. Investigation Of HDPE Plastic Waste Aggregate On The Properties Of Concrete. Journal of Asian Scientific Research, 1(7), pp. 340-345. (2011)

5. Choi, Y.W., Moon, D.J., Chung, J.S., Cho, S.K., Effects of waste PET bottles aggregate on properties of concrete. Cem. Concr. Res 35 (4), 776-781. (2005)

6. Yazoghli-Marzouk, O., Dheilly, R.M., Queneudec, M., Valorization of postconsumer waste plastic in cementitious concrete composites. Waste manage. 27 (2), 310-318. (2007)

7. Sobhan, K.H., Mashna, M., Tensile strength and toughness of soil-cement-flyash composite reinforced with recycled high-density polyethylene strips. J. Mater. Civ. Eng. 14 (2), 177-184. (2002)

8. Vaverka, J.V. An analysis of reinforced concrete composites utilizing recycled polyethylene terephthalate thermoplastic. Ph.D. thesis. Northern Iowa University, Cedar Falls, IA, University Microfilms International, LD2585. (1991)

9. Ismail, Z.Z., AL-Hashmi, E.A.,. Use of waste plastic in concrete mixture as aggregate replacement. Waste Manage. 28 (11), 2041-2047. (2008)

10. Naik TR, Singh SS, Huber CO, Brodersen BS. Use of post-consumer plastic wastes in cement-based composites. Cem Concr Res. 26:1489-92. (1996)

11. Mulyono, Tri. Teknologi Beton.Yogyakarta : Penerbit Andi. (2004)

12. Tjokrodimuljo, Kardiyono. Teknologi Beton. Yogyakarta: Biro Penerbit Teknik Sipil Universitas Gajah Mada. (2009)

13. Nursyamsi., Winner S.B.Z. . The influence of PET plastic waste gradations as coarse aggregate 
towards compressive strength of light concrete.

Procedia Engirneering 171:614-619. (2017)

14. Permatatasari, Reby Indah. Pengaruh Serbuk Kaca Terhadap Properties Batako. Tugas Akhir Program Studi Teknik Sipil Universitas Sumatera utara. Medan. (2015)

15. Fathur, Muhammad. Pengaruh Penambahan Serbuk Kaca Pada BatakoSebagai Bahan Pembuatan Dinding. Universitas Sumatera Utara . Medan . (2016) 